Michat Pachocki

Fundacja Rozwoju Systemu Edukacji

Narodowa Agencja Programu Erasmus+ w Polsce e-mail: mpachocki@frse.org.pl

\title{
JAK MOBILNI NAUCZYCIELE ZMIENIAJĄ EDUKACJĘ? OBRAZ POLSKIEJ SZKOŁY W KONTEKŚCIE WYNIKÓW BADANIA WPŁYWU ZAGRANICZNYCH SZKOLEŃ KADRY NA POLSKIE PLACÓWKI EDUKACYJNE
}

\begin{abstract}
How mobile teachers change the education? The image of Polish schools in research on the impact of staff training abroad on educational institutions in Poland

The article provides overview on results of research concerning Erasmus + staff transnational mobility impact on Polish schools. It is also an attempt to deliver diagnosis of needs and problems schools face while using EU funds to carry out activities difficult to fund from domestic resources.
\end{abstract}

Keywords: internationalisation of schools, mobility training of teachers

\section{Streszczenie}

Artykuł przedstawia wyniki badania wpływu zagranicznych szkoleń nauczycieli w programie Erasmus+ na polskie placówki edukacyjne. Jest również próbą diagnozy potrzeb i problemów szkół, które często dzięki funduszom unijnym realizują działania trudne do sfinansowania w ramach dostępnych środków krajowych.

Słowa kluczowe: umiędzynarodowienie szkół, mobilność edukacyjna nauczycieli 


\section{Wprowadzenie}

Chociaż w polskim systemie oświaty funkcjonuje wiele instytucji publicznych odpowiedzialnych za doskonalenie zawodowe nauczycieli, brak w nim istotnych instrumentów finansowych (zarówno na poziomie centralnym, jak i lokalnym), które pozwalałyby na systemowe delegowanie środków na szkolenia kadry dydaktycznej za granicą. Główne wsparcie w tym zakresie oferują przede wszystkim fundusze europejskie, a dostęp do podobnej oferty szkoleniowej z funduszy krajowych jest bardzo utrudniony, jeśli nie niemożliwy [Smoczyńska i in., 2014]. Najważniejszym źródłem finansowania zagranicznych wyjazdów szkoleniowych dla nauczycieli jest program Erasmus+, który wspiera sektor edukacji szkolnej w krajach Unii Europejskiej, państwach ubiegających się o członkostwo w UE oraz w krajach stowarzyszonych z UE w ramach EFTA/EOG [Rozporządzenie Parlamentu Europejskiego i Rady nr 1288/2013...]. Zgodnie z założeniami programu udział nauczycieli w zagranicznych kursach i szkoleniach ma na celu przede wszystkim poprawę jakości pracy szkoły poprzez zwiększanie kompetencji dydaktycznych jej pracowników [Erasmus + Programme Guide..., 2014: 55].

Opisane w artykule badanie zostało zainicjowane przez Litewską Narodową Agencję Programu Erasmus+ w celu dokonania jakościowej analizy wpływu projektów na środowisko szkolne. Chociaż przedstawione wyniki dotyczą jedynie polskiej grupy respondentów, należy wspomnieć, że podobne aktywności (zrealizowane zgodnie z zestandaryzowaną, opracowaną przez litewskich ekspertów metodologią) zrealizowano również w Niemczech, Estonii, Finlandii oraz na Litwie [Balčiūnas i in., 2017].

\section{Kontekst metodologiczny}

Jednym z głównych celów realizowanych aktywności badawczych było sprawdzenie, czy oferowane przez program formy podnoszenia kompetencji (przede wszystkim kursy i szkolenia) miały rzeczywisty wpływ na zmianę postaw zawodowych, przy założeniu, że rozwój zawodowy nauczycieli oznacza nie tylko zdobywanie nowej wiedzy, ale przede wszystkim jej praktyczne zastosowanie w procesie kształcenia uczniów [Avalos, 2011]. W badaniu wykorzystano techniki ilościowe (kwestionariusz internetowy) oraz jakościowe (wywiady i studia przypadków). Szczegółowe wyniki oraz kontekst metodologiczny zostały opisane w raporcie podsumowującym całość rezultatów przedstawionego projektu badawczego [Pachocki, 2016].

W badaniu ankietowym brali udział uczestnicy wyjazdów, pozostali nauczyciele, uczniowie w wieku powyżej 15 lat oraz ich rodzice (tabela 1). Łącznie otrzymano ponad 1700 wypełnionych kwestionariuszy, z których ponad 30\% stanowiły ankiety wypełnione przez uczniów. Oprócz części kwestionariuszowej w ramach badania zrealizowano wywiady grupowe z 25 przedstawicielami szkół z różnych regionów Polski oraz studia przypadku wybranych dobrych praktyk (trzech projektów, których realizacja zakończyła się szczególnym powodzeniem). Łącznie 
w badaniu uczestniczyło 46 placówek edukacyjnych, które otrzymały dofinansowanie na realizację projektów w 2014 roku (w ramach pierwszego naboru wniosków) i w momencie realizacji aktywności badawczych zakończyły już realizację wszystkich zaplanowanych szkoleń za granicą. Wszystkie realizowane aktywności badawcze miały charakter anonimowy (rezygnowano ze zbierania danych o uczestnikach zarówno ilościowej, jak i jakościowej części badania).

Tabela 1

Podsumowanie realizacji badania ankietowego on-line. Zestawienie wypełnień kwestionariuszy w podziale na grupy docelowe badania w Polsce

\begin{tabular}{|l|c|c|c|c|}
\cline { 2 - 5 } \multicolumn{1}{c|}{} & $\begin{array}{c}\text { Uczestnicy } \\
\text { mobilności }\end{array}$ & $\begin{array}{c}\text { Inni } \\
\text { nauczyciele }\end{array}$ & $\begin{array}{c}\text { Uczniowie } \\
\text { w wieku powyżej } \\
\text { 15 lat }\end{array}$ & $\begin{array}{c}\text { Rodzice } \\
\text { uczniów }\end{array}$ \\
\hline $\begin{array}{l}\text { Liczba wypelnionych } \\
\text { kwestionariuszy }\end{array}$ & 350 & 412 & 596 & 429 \\
\hline $\begin{array}{l}\text { Maksymalna liczba } \\
\text { respondentów } \\
\text { w każdej badanej szkole }\end{array}$ & $\begin{array}{c}\text { wszyscy } \\
\text { uczestnicy }\end{array}$ & 10 & 20 & 10 \\
\hline Odsetek populacji & $19,6 \%$ & $23 \%$ & $33,4 \%$ & $24 \%$ \\
\hline
\end{tabular}

Źródło: M. Pachocki, Mobilni nauczyciele zmieniają swoje szkoły, Warszawa 2016, s. 5.

Wybór szerokiej grupy docelowej badania (wykraczającej poza grono pedagogiczne) wynikał z przyjętego założenia, że doskonalenie zawodowe nauczycieli ma sens przede wszystkim wtedy, gdy prowadzi do refleksji nad jakością pracy dydaktycznej zarówno w kontekście realizacji programów nauczania, jak i w odniesieniu do pozostałych aspektów działalności danej szkoły [Postholm, 2012]. Przedstawione wyniki stanowią więc także próbę odpowiedzi na pytanie, czy podnoszenie kompetencji zawodowych za granicą ma wpływ nie tylko na wyjeżdżających nauczycieli, ale również na ich macierzystą szkołę oraz jej otoczenie. Ponieważ badanie umożliwiło diagnozę problemów i potrzeb polskich placówek edukacyjnych, niniejszy artykuł - w odróżnieniu od publikacji przedstawiających jedynie korzyści z realizacji programów unijnych - stanowi również próbę pokazania trudności, z jakimi spotykają się w swojej pracy polscy nauczyciele, oraz sposobów ich rozwiązywania poprzez uczestnictwo w zagranicznych szkoleniach. Z pozyskanych danych wyłania się bowiem obraz szkół starających się przez recepcję funduszy unijnych realizować takie działania, dla których próżno szukać wsparcia w ramach środków pochodzących z własnych budżetów oraz innych funduszy krajowych. 


\section{Problemy z umiędzynarodowieniem szkół}

W obliczu trwającej obecnie dyskusji o konieczności zwiększenia poziomu internacjonalizacji polskich instytucji szkolnictwa wyższego stwierdzić należy, że niewiele miejsca $\mathrm{w}$ debacie o polskim systemie edukacji poświęca się potencjalnym korzyściom $\mathrm{z}$ umiędzynarodowienia placówek funkcjonujących w sektorze oświaty. Tymczasem to właśnie umiędzynarodowienie kształcenia na wszystkich jego poziomach zostało wskazane przez Komisję Europejską jako jeden z kontekstów systemowych istotnych dla wdrażania programu Erasmus+ [Erasmus + Programme Guide, 2014: 12]. Jednym z kluczowych założeń programu jest bowiem wpisanie okresu mobilności zagranicznej zarówno $\mathrm{w}$ długoterminową strategię rozwoju, jak i w ogólny kontekst funkcjonowania danej instytucji kształcenia.

Ze względu na niełatwy dostęp do oferty szkoleń zagranicznych w Polsce znaczna część badanych instytucji nie realizowała wcześniej podobnych projektów. Wcześniejszy udział w zagranicznych szkoleniach potwierdziło tylko 33,2\% respondentów ankiety, a zdecydowana większość uczestników wywiadów deklarowała, że udział w mobilności był ich pierwszym w życiu wyjazdem za granicę. Również większość badanych uczniów $(73,7 \%)$ nie brała nigdy udziału w zagranicznych projektach edukacyjnych. Fakt, że obie te grupy nie miały większych doświadczeń w obszarze współpracy międzynarodowej, wynika również z dużej konkurencji wśród szkół aplikujących do programu, która przekłada się na relatywnie niski współczynnik sukcesu (w 2014 roku, kiedy realizowano badanie, dofinansowanie otrzymał jedynie co czwarty wnioskodawca).

Wyniki badania pokazują jednak, że umożliwienie szkołom współpracy międzynarodowej przez dofinansowanie zagranicznych szkoleń dla nauczycieli wywarło pozytywny wpływ zarówno na samych uczestników takich szkoleń, jak i na instytucje, w których pracują. Respondenci z wszystkich badanych grup wskazywali, że pobyt nauczycieli za granicą przyczynił się nie tylko do zdobycia przez nich nowej wiedzy, ale również do ogólnego podniesienia jakości funkcjonowania szkoły. Zarówno w opinii nauczycieli, jak i uczniów wypracowane efekty współpracy zagranicznej odgrywają istotną rolę nie tylko na poziomie kształcenia, ale również w wymiarze społecznym (wpływ na kulturę szkoły, w tym na promowane przez nią postawy oraz wartości). Zdecydowana większość uczniów potwierdziła, że zagraniczna współpraca pomiędzy nauczycielami z różnych krajów odgrywa istotną rolę dla rozwoju szkoły $(92,9 \%)$. Stosunkowo często pojawiały się również deklaracje dotyczące gotowości uczniów do udziału w projektach, w które zaangażowana byłaby także młodzież z innych państw (91,6\%), oraz chęci uczestniczenia w uczniowskich wymianach zagranicznych $(94,2 \%$ - zob. wykres 1). Zdecydowanie gorzej uczniowie ocenili natomiast realne zmiany na rzecz umiędzynarodowienia swoich szkół (63,1\% respondentów potwierdziło, że nauczyciele po powrocie $\mathrm{z}$ wyjazdów organizują zdalną pracę $\mathrm{z}$ innymi uczniami z zagranicy - zob. wykres 2). To, jak ważne jest rozwijanie współpracy międzynarodowej w szkołach, potwierdzają również deklaracje rodziców - zob. wykres 2 . Niemal wszyscy respondenci z tej grupy $(99,3 \%)$ potwierdzili, że ważne 


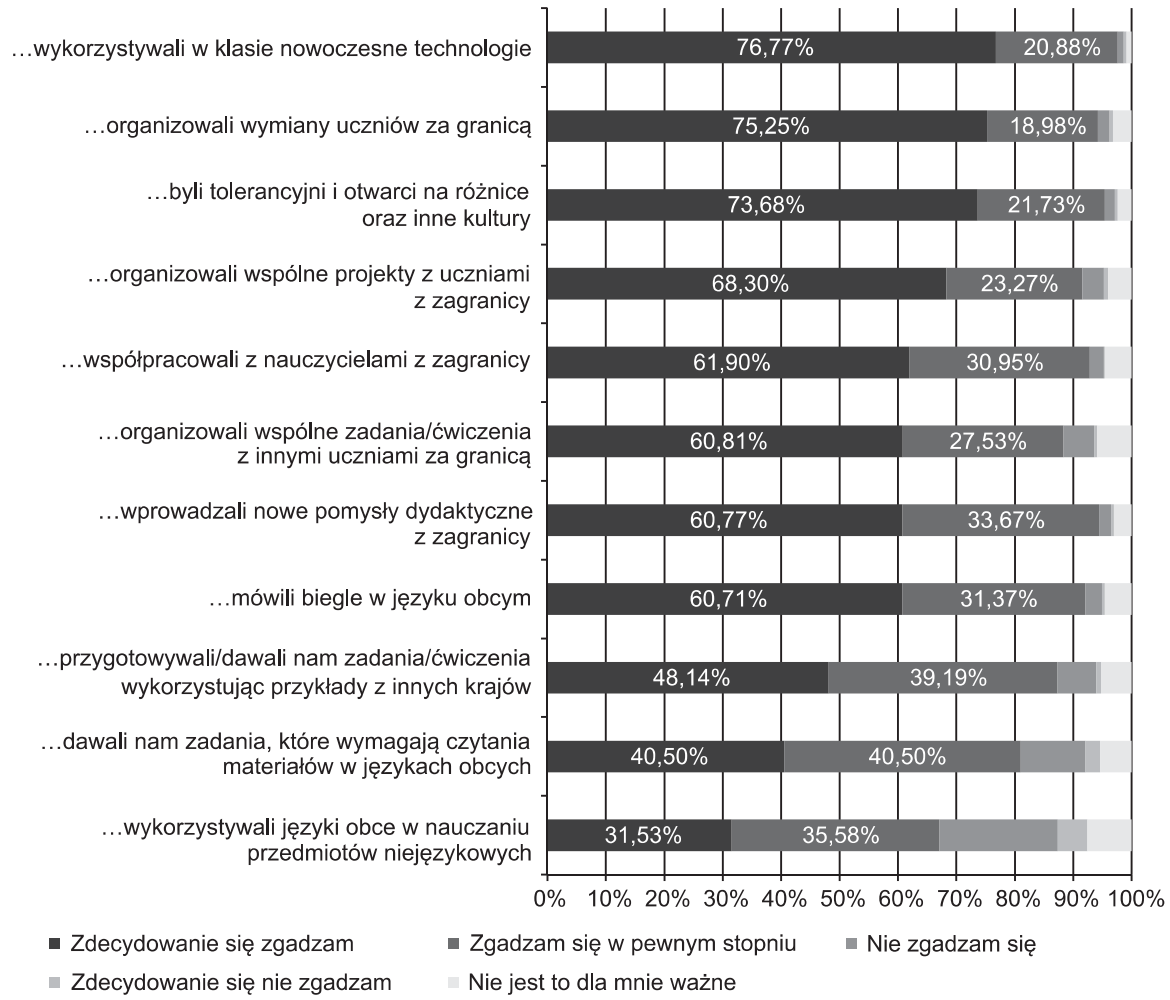

Wykres 1. Rezultaty mobilności nauczycieli w opinii uczniów (zestawienie odpowiedzi na pytanie: „Jak ważne jest dla Ciebie, aby Twoi nauczyciele...?”)

Źródło: M. Pachocki, Mobilni nauczyciele zmieniają swoje szkoły, Warszawa 2016, s. 24.

jest dla nich zdobywanie przez uczniów kompetencji w tym obszarze. Rodzice dostrzegli nie tylko istotny związek pomiędzy mobilnościami i rozwojem szkoły (96\%), ale również pomiędzy realizacją projektów a poprawą wyników osiąganych przez uczniów $(95,5 \%)$.

\section{Problemy ze znajomością języków obcych}

W opinii badanych nauczycieli problem niskiego poziomu umiędzynarodowienia polskich szkół wynika bezpośrednio również z niskich kompetencji językowych kadry, których niedostatek w znacznym stopniu utrudnia podejmowanie współpracy ze szkołami z innych krajów. W dyskusji o polskiej oświacie od wielu lat pojawiają się głosy, że warunkiem korzystania z możliwości udziału w europejskim systemie edukacyjnym jest odpowiedni poziom znajomości języków obcych [Ordon, 2007], przy czym takie postulaty nie dotyczą jedynie 


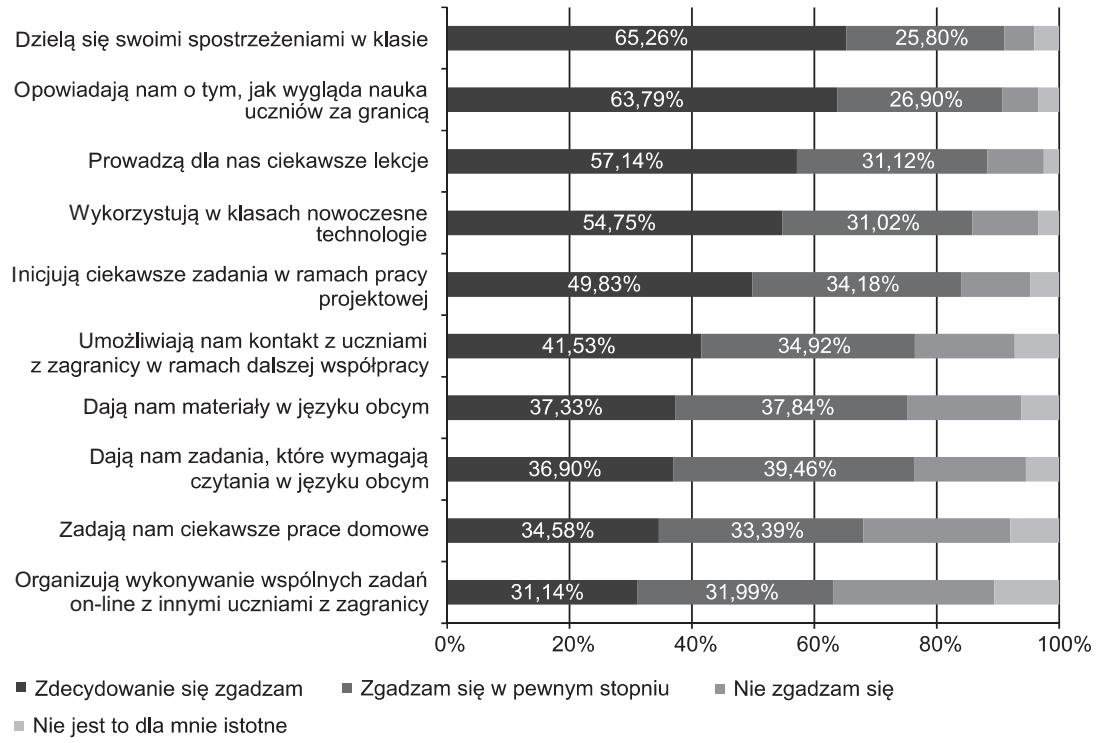

Wykres 2. Rezultaty mobilności nauczycieli w opinii uczniów (Zestawienie odpowiedzi na pytanie wielokrotnego wyboru: „Jak zachowują się nauczyciele po powrocie z wyjazdów szkoleniowych za granicą?")

Źródło: M. Pachocki, Mobilni nauczyciele zmieniają swoje szkoły, Warszawa 2016, s. 25.

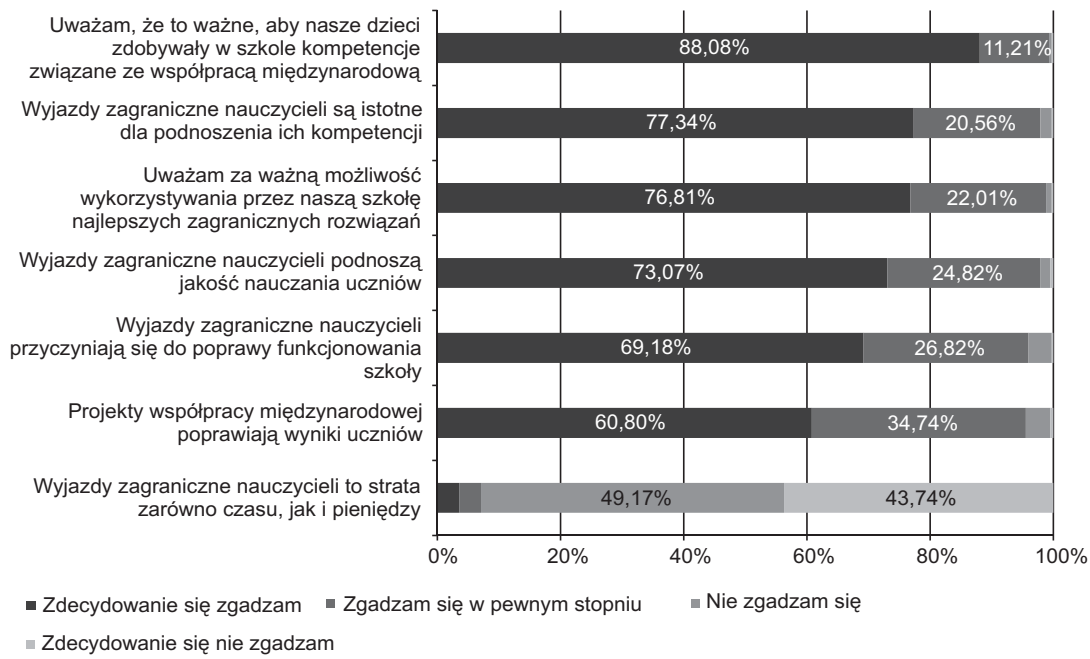

Wykres 3. Internacjonalizacja szkół w opinii rodziców (rozkład odpowiedzi na pytanie: „Jaka jest Państwa opinia na temat poziomu umiędzynarodowienia szkoły, w której uczy się Państwa dziecko?”)

Źródło: M. Pachocki, Mobilni nauczyciele zmieniaja swoje szkoły, Warszawa 2016, s. 26. 


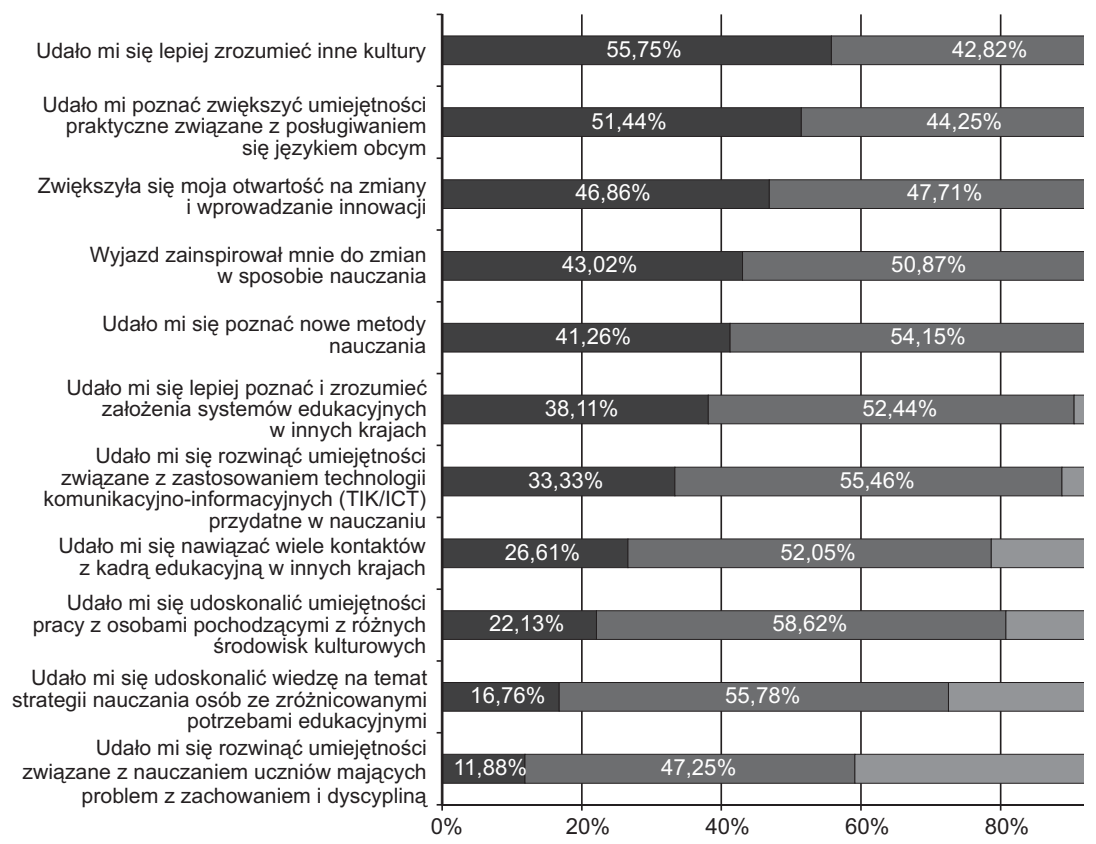

Wykres 4. Korzyści z realizacji szkoleń w opinii uczestników szkoleń zagranicznych (Zestawienie odpowiedzi na pytanie wielokrotnego wyboru: „W jaki sposób wdrażają Państwo pomysły zaczerpnięte podczas realizacji mobilności?”)

Źródło: M. Pachocki, Mobilni nauczyciele zmieniaja swoje szkoty, Warszawa 2016, s. 23.

nauczycieli przedmiotów językowych, ale również innych pracowników dydaktycznych w szkołach. Wyniki badania pokazały jednak, że inicjatorami współpracy międzynarodowej w polskich placówkach edukacyjnych są przede wszystkim nauczyciele przedmiotów językowych. Zgodnie z deklaracjami badanych nauczycieli wynika to przede wszystkim z bariery językowej, która utrudnia innym nauczycielom podejmowanie kontaktów z partnerami z innych krajów.

Można uznać, że to właśnie niewystarczająca znajomość języka obcego przed wyjazdem spowodowała, że jedną z najważniejszych deklarowanych korzyści z realizacji mobilności okazała się poprawa znajomości języków obcych (wykres 4). Badani nauczyciele zwracali uwagę, że zwiększenie kompetencji językowych wpłynęło pozytywnie nie tylko na rozwój zawodowy uczestników, ale również na podniesienie potencjału dydaktycznego szkół. Zgodnie z deklaracjami respondentów lepsze posługiwanie się językiem obcym (przede wszystkim językiem angielskim) pozwoliło uczestnikom szkoleń na częstsze i bardziej efektywne wykorzystywanie obcojęzycznych materiałów i pomocy dydaktycznych. Niejednokrotnie udział w zagranicznych szkoleniach przyczynił się również do poszerzenia wiedzy uczestników na temat źródeł poszukiwania takich materiałów (np. 
ogólnodostępnych platform anglojęzycznych). Istotną rolę, jaką odgrywają mobilności zagraniczne w obszarze kompetencji językowych, potwierdzają również deklaracje części badanych nauczycieli, dla których wyjazd na szkolenie wiązał się przede wszystkim z koniecznością nauki języka obcego od podstaw.

Respondenci często podkreślali, że nauka języka obcego w Polsce często jest utożsamiana przede wszystkim z przyswajaniem struktur gramatycznych. Sprawą drugorzędną okazuje się natomiast nabywanie w trakcie nauki kompetencji kluczowych związanych z porozumiewaniem się w języku obcym. Zarówno to, jak i brak wcześniejszych doświadczeń związanych z używaniem języka obcego za granicą stanowiły czynnik blokujący komunikację i powodujący barierę językową. Bariera komunikacyjna szybko znikała jednak podczas pierwszych kontaktów z obcokrajowcami (szczególnie kiedy okazywało się, że im również zdarza się popełniać błędy). W takim wypadku mobilności odgrywały istotną rolę w przełamywaniu bariery językowej i pokonywania stresu związanego z porozumiewaniem się w języku obcym.

Uczestnictwo w zagranicznych szkoleniach miało również zauważalny wpływ na środowisko szkolne, przede wszystkim w odniesieniu do wzrostu kompetencji językowych pozostałych nauczycieli i uczniów. Wielu uczestników zauważyło, że im bardziej dany projekt angażuje merytorycznie kadrę, tym bardziej korzystają na tym uczniowie (poznane metody są wówczas chętniej wykorzystywane podczas realizowanych zajęć dydaktycznych). Dotyczy to zwłaszcza posługiwania się językiem obcym jako narzędziem do realizacji programów nauczania przedmiotów niejęzykowych. Szczególne korzyści w tym obszarze deklarowali nauczyciele, którzy na co dzień pracują w szkołach realizujących elementy nauczania dwujęzycznego. Wśród zmian, które chcieliby wprowadzić w wyniku realizacji projektu, respondenci często wymieniali także wprowadzenie elementów metody CLIL (Content and Language Integrated Learning), polegającej na jednoczesnym przekazywaniu treści programów nauczania przedmiotów niejęzykowych i elementów nauki języka obcego. Zdecydowanie mniejszy entuzjazm wobec wykorzystywania języków obcych w nauczaniu innych przedmiotów niejęzykowych dostrzegają natomiast uczniowie (tylko 67\% respondentów z tej grupy postulowało większe wykorzystywanie obcojęzycznych materiałów dydaktycznych podczas lekcji). Warto jednak dodać, że w opinii nauczycieli wykorzystywanie języka angielskiego do prowadzenia zajęć $\mathrm{z}$ innych przedmiotów w znacznym stopniu zmieniło podejście uczniów do nauki innych języków. Co więcej, część respondentów wywiadów deklarowała, że pokonanie bariery językowej przez nauczycieli sprawiło, że stali się oni dla uczniów wzorem do naśladowania oraz dowodem na to, że warto uczyć się języków obcych.

Należy jednak dodać, że w opinii wielu uczestników szkoleń polskim nauczycielom często trudno jest przenieść wykorzystywane przez nich na co dzień metody pracy z uczniem na pracę w języku innym niż język polski. W dużej mierze wynika to zarówno z opisanej powyżej bariery językowej, jak i z braku umiejętności poszukiwania obcojęzycznych materiałów w otwartych zasobach edukacyjnych. Uczestnicy wywiadów deklarowali jednak, że doświadczenia zdobyte podczas zagranicznych mobilności są dobrą okazją do uzupełnienia takich braków 
kompetencyjnych i stwarzają perspektywę wzbogacenia warsztatu pracy nauczyciela, chociażby dzięki możliwości wymiany doświadczeń z przedstawicielami innych zagranicznych instytucji partnerskich.

\section{Niskie kompetencje informatyczne}

Kolejnym bardzo ważnym obszarem problemów, które starano się rozwiązać przez udział w zagranicznych mobilnościach, był brak wystarczającej znajomości technologii komunikacyjno-informacyjnych (TIK) wśród kadry szkół uczestniczących w projektach. Deklarowane niedostatki w tym obszarze wydają się szczególnie istotne, chociażby w kontekście realizowanych reform systemu oświaty, w tym wprowadzania treści programowych związanych z nauczaniem programowania oraz kodowania w edukacji wczesnoszkolnej (również w kontekście deklarowanych obecnie zmian systemowych). Często okazuje się bowiem, że proces informatyzacji i wprowadzania nowych technologii do polskich placówek edukacyjnych kończy się wraz z pozyskaniem środków finansowych i zakupem nowego sprzętu [Białek, Rybińska, 2013]. Niejednokrotnie było to związane z wcześniejszym doposażeniem szkoły w nowoczesny sprzęt, z którego jednak nie korzystano z powodu braku wystarczającej wiedzy i kompetencji kadry (pomimo dostępnych środków na jego zakup nie udało się uzyskać funduszy na szkolenia informatyczne grona pedagogicznego). Zasadniczym celem znacznej części projektów było więc zwiększenie efektywnego korzystania z nowych technologii i urządzeń w ramach prowadzonych lekcji, ze szczególnym uwzględnieniem nauczania przedmiotów innych niż informatyka.

Deklaracje respondentów potwierdzają, że poznanie nowych programów i narzędzi cyfrowych umożliwiło im lepsze i bardziej efektywne realizowanie procesu kształcenia, chociażby dzięki możliwości wprowadzania do porządku lekcji elementów interakcji, większego angażowania klasy czy też wprowadzania ciekawszych form zadań domowych. Uczestnicy wywiadów często deklarowali, że chociaż TIK warto wykorzystywać szczególnie w starszych klasach szkoły podstawowej i gimnazjum, to podobne narzędzia można również z powodzeniem stosować w nauczaniu wczesnoszkolnym, także w ramach zajęć dodatkowych, np. wykorzystując poznane podczas szkoleń programy komputerowe do obróbki obrazu, dźwięku czy też samodzielnego tworzenia wirtualnych postaci (tzw. awatarów) do celów edukacyjnych (np. nauki języków obcych).

Świadomość konieczności zwiększenia wiedzy w zakresie TIK wynikała również z dostrzegania ogólnych zmian w postrzeganiu i korzystaniu z nowych technologii przez kolejne roczniki uczniów rozpoczynających edukację. Wielu badanych nauczycieli wskazywało, że wykorzystywanie TIK zdecydowanie zwiększa szanse na rzeczywiste zaangażowanie uczniów w proces uczenia się i samodzielnego zdobywania wiedzy. Potwierdzili to również sami uczniowie, którzy deklarowali, że ważne jest dla nich zarówno wykorzystywanie przez nauczycieli nowych technologii $(97,7 \%)$, jak i wprowadzanie innowacyjnych pomysłów dydaktycznych z zagranicy $(94,4 \%)$. 
Co ciekawe, zgodnie z deklaracjami respondentów nowa wiedza kadry w zakresie TIK wpłynęła również na zmianę podejścia do sformalizowanego porządku lekcji oraz odgórnie przyjętych ról w relacji pomiędzy uczniami a nauczycielem. Ciekawym przykładem takiej zmiany okazało się nowe podejście do stosowania (dotychczas zabronionych podczas zajęć) prywatnych telefonów komórkowych uczniów. Dla części respondentów ważnym odkryciem okazało się to, że w instytucjach partnerskich uczniowie często wykorzystują swoje telefony jako pomoce naukowe w ramach realizowanych zadań, wyszukując informacje i materiały źródłowe w zasobach internetu bądź też rozwiązując zadania matematyczne przy użyciu dostępnej w telefonie funkcji kalkulatora.

\section{Brak zaangażowania}

Zarówno dla nauczycieli biorących udział w wyjazdach, jak i dla pozostałych pracowników dydaktycznych szkół niezwykle istotnym obszarem deklarowanych korzyści z realizacji projektu były (oprócz zdobytych nowych kompetencji) zmiany postaw oraz zmiany, które zachodziły w placówkach w wyniku upowszechniania rezultatów projektów. Okazały się one szczególnie ważne w kontekście deklarowanego przez respondentów kryzysu postaw, jaki w ostatnich latach dotyka polską szkołę. W opinii respondentów kryzys ten dotyczy przede wszystkim braku motywacji, a dotyka zarówno samych nauczycieli, jak i uczniów.

Badani nauczyciele często wskazywali na niedostateczną autonomię i brak motywacji uczniów do samodzielnego zdobywania wiedzy. W tym kontekście podnoszono również kwestie związane z postawami rodziców - nadmiernie autorytarnymi lub nazbyt opiekuńczymi. Respondenci zwracali też uwagę, że polscy nauczyciele coraz częściej, już po kilku latach pracy, doświadczają wypalenia zawodowego. Wynika to m.in. z braku systemowego motywowania kadry do podnoszenia kompetencji dydaktycznych. Pomimo dużej dostępności szkoleń w Polsce oferowane kursy często dotyczą bardzo podobnych obszarów, a udział w nich wynika raczej z konieczności i presji kierownictwa szkoły niż realnych potrzeb. Zagraniczna mobilność edukacyjna jest w tym kontekście postrzegana jako bardziej atrakcyjna i pożądana forma podnoszenia kompetencji zawodowych. Często już sam udział w projekcie wpływa na zmianę postaw zawodowych jego uczestników. Zwracano też uwagę, że niejednokrotnie już samo podzielenie się zdobytą wiedzą w gronie pedagogicznym ma pozytywny wpływ zarówno na środowisko szkolne, jak i na otoczenie danej placówki (zob. wykres 5).

Niemal wszyscy respondenci potwierdzili, że nową wiedzą i zdobytym doświadczeniem podzielili się również z innymi nauczycielami (94,6\%). Jednocześnie większość badanych nauczycieli opracowała po powrocie z wyjazdu nowe materiały dydaktyczne (76\%), a wielu z nich wdraża nowe pomysły, dzieląc się wiedzą z rodzicami uczniów $(63,4 \%)$. Przekazywanie zdobytej wiedzy i nowych umiejętności zawodowych odbywa się głównie w ramach szkoły realizującej projekt. Chociaż ponad połowa ankietowanych uczestników mobilności potwierdziła 


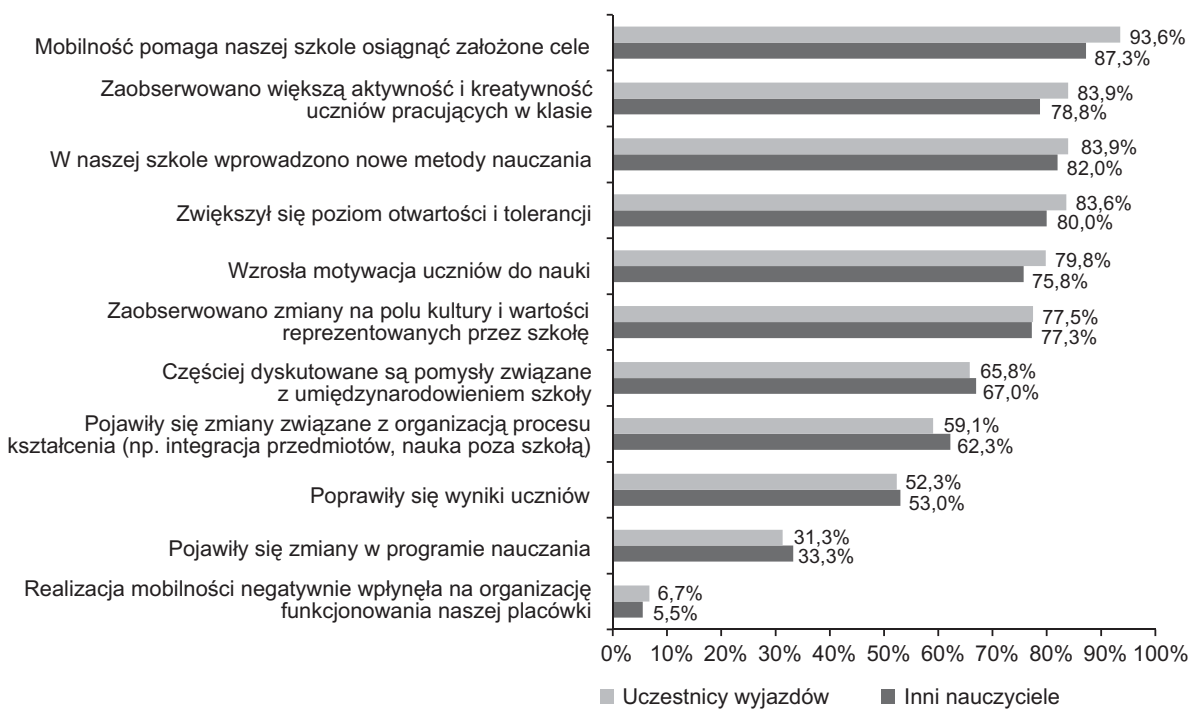

Wykres 5. Ocena korzyści zagranicznych szkoleń kadry dla macierzystej placówki wysyłającej (zestawienie odpowiedzi na zadanie wielokrotnego wyboru: „Po zakończeniu realizacji mobilności kadry edukacji szkolnej w ramach programu Erasmus + ...”, udzielonych przez uczestników projektów oraz pozostałych nauczycieli ze szkół objętych badaniem; zestawienie pokazuje, jaki odsetek respondentów zgodził się z danym stwierdzeniem)

Źródło: M. Pachocki, Mobilni nauczyciele zmieniają swoje szkoły, Warszawa 2016, s. 21-22.

przygotowanie prezentacji w związku z udziałem w konferencjach, to zdecydowanie mniej osób zadeklarowało współpracę z przedstawicielami innych instytucji, potencjalnie zainteresowanych wynikami projektu w ramach uczestnictwa we wspólnych seminariach (13,7\%), czy też opracowywania stosownych rekomendacji (13,4\% - zob. wykres 6).

Również uczniowie pozytywnie ocenili efekty zrealizowanych mobilności. Ponad $90 \%$ z nich potwierdziło, że nauczyciele dzielą się swoimi spostrzeżeniami i opowiadają o tym, jak wygląda nauka za granicą. Również wśród rodziców uczniów przeważała opinia, że realizowane mobilności przynoszą szkole zdecydowanie więcej korzyści niż strat. Pozytywnie oceniono przekazywanie przez nauczycieli informacji na temat celów i efektów realizowanych wyjazdów. Rodzice zauważyli również wagę, jaką odgrywają dla szkół działania na rzecz umiędzynarodowienia. Potwierdzili także, że szkoła sama angażuje ich w takie działania. Należy jednak zaznaczyć, że to rodzice częściej niż nauczyciele zauważali ryzyko zaniedbywania funkcji edukacyjnej szkoły w związku z realizacją projektów (12,8\% respondentów zauważyło, że wskutek mobilności kadry uczniowie tracą lekcje - zob. wykres 7). 
Przez ustne sprawozdanie podczas spotkania z gronem pedagogicznym/radą pedagogiczna

Opracowując nowe materiały dydaktyczne przydatne w realizacji nauczania swojego przedmiotu

Dzieląc się wiedzą z rodzicami

Przygotowując prezentację na konferencji dla innych nauczyciel

Zapraszając na swoje lekcje innych współpracowników

Przez zamieszczenie przygotowanych materiałów w wersji on-line ( $\mathrm{np}$. facebook, moodle etc.)

Dzieląc się swoimi pomysłami związanymi z realizacją mobilności w mediach (TV, prasa)

Przez realizację seminarium dla innych uczestników poza szkoła

Opracowując rekomendacje odnośnie do organizacji procesu nauczania

Żadne działania upowszechniające nie zostały przeze mnie zrealizowane

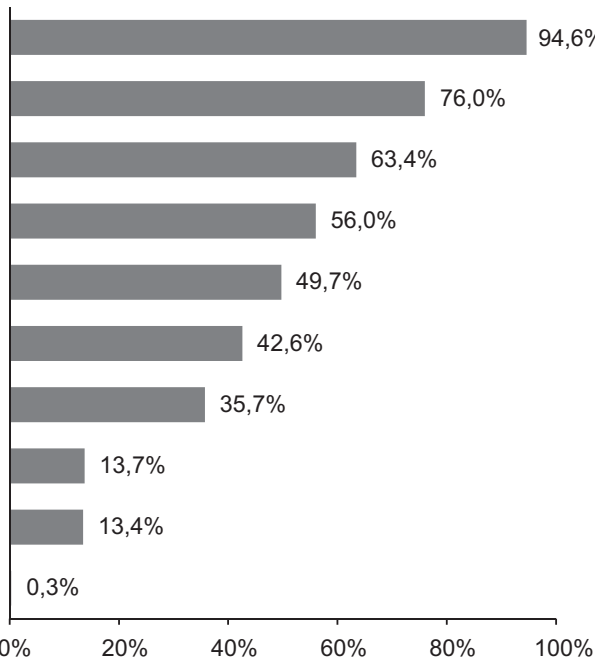

Wykres 6. Upowszechnianie rezultatów szkoleń przez uczestników wyjazdów (rozkład odpowiedzi na pytanie wielokrotnego wyboru: „W jaki sposób podzielili się Państwo zdobytą wiedzą i doświadczeniem po zakończeniu mobilności?”; zestawienie pokazuje, jaki odsetek respondentów zgodził się z danym stwierdzeniem)

Źródło: M. Pachocki, Mobilni nauczyciele zmieniają swoje szkoły, Warszawa 2016, s. 19.

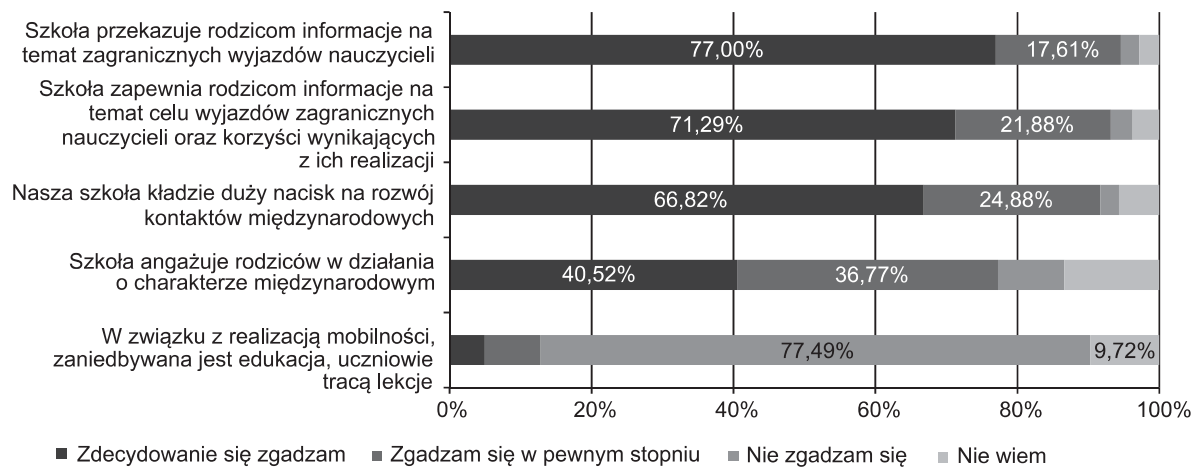

Wykres 7. Identyfikacja korzyści z realizacji zagranicznych szkoleń nauczycieli w opinii rodziców (rozkład odpowiedzi na pytanie: ,Jaka jest Państwa opinia na temat działań międzynarodowych realizowanych w szkole, w której uczy się Państwa dziecko?”)

Źródło: M. Pachocki, Mobilni nauczyciele zmieniają swoje szkoły, Warszawa 2016, s. 26. 


\section{Podsumowanie}

Wyniki badania pozwalają sądzić, że realizacja zagranicznych szkoleń kadry pomaga nie tylko rozwinąć kompetencje samych uczestników, ale również w znacznym stopniu wpływa na funkcjonowanie całej placówki i jej otoczenia. Możliwość obserwacji ciekawych rozwiązań systemowych i organizacyjnych w wielu przypadkach skłaniała uczestników do refleksji nad stanem polskiej szkoły oraz kondycji zawodu nauczyciela. Takie refleksje niejednokrotnie przyczyniły się do wprowadzenia zmian $w$ instytucjach macierzystych uczestników. Wiele z takich zmian wynikało bezpośrednio ze zmiany postaw zarówno wśród nauczycieli, jak i uczniów oraz ich rodziców. Opisane w artykule obszary nie wyczerpują wszystkich deklarowanych korzyści oraz zmian zachodzących w polskich szkołach w wyniku realizacji badanych projektów. Wśród nauczycieli biorących udział w mobilnościach przeważała opinia, że organizacja wyjazdów w pełni przyczyniła się do osiągnięcia założonych celów projektowych, a realizowane mobilności przyniosły szkołom szereg korzyści. Zdecydowana większość badanych uznała też, że zagraniczne szkolenia przyczyniły się do wprowadzania nowych form nauczania. Przedstawiciele niemal wszystkich badanych szkół potwierdzili, że zmian, które zaistniały w wyniku szkoleń, nie udałoby się zrealizować bez dostępności środków europejskich. Zebrane deklaracje pozwalają również sądzić, że wypracowane w ramach projektu rezultaty będą miały charakter trwały i nie tylko przyczynią się do rozwoju kompetencji nauczycieli, ale również w znacznym stopniu wpłyną na jakość funkcjonowania polskich szkół. Większość badanych uczestników postrzega zdobyte podczas wyjazdów doświadczenia przede wszystkim w kontekście wzmocnienia potencjału całego grona pedagogicznego. Jest to szczególnie ważne w kontekście deklarowanych zmian, zachodzących pod wpływem mobilności również w tych obszarach, w których jakiekolwiek innowacje czy usprawnienia nie były wcześniej planowane. Pozwala to żywić nadzieje, że środki przeznaczone na realizację indywidualnych wyjazdów szkoleniowych okażą się inwestycją w poprawę funkcjonowania całych instytucji, a być może $\mathrm{w}$ dalszej perspektywie - w realizację zmian systemowych w polskiej oświacie. Kluczową rolę $\mathrm{w}$ tym procesie odegrają jednak sami nauczyciele, ponieważ to właśnie ich optymizm i zaangażowanie warunkują dzielenie się doświadczeniami oraz nową wiedzą przywiezioną z zagranicy.

\section{Bibliografia}

Avalos B. (2011), Teacher Professional Development in Teaching and Teacher Education over Ten Years, „Teaching and Teacher Education: An International Journal Of Research And Studies", 1(27).

Balčiūnas S., Damkuvienė M, Valuckienė J. (2017), Impact and Sustainability of the Erasmus + Programme Key Action 1 Mobility Projects for School Education Staff. Research Report, Siaulai. 
Białek M., Rybińska A. (2013), Wykorzystanie TIK w nauczaniu i uczeniu się uczniów ze SPE na przykładzie rządowego programu rozwijania kompetencji uczniów i nauczycieli w zakresie stosowania technologii informacyjno-komunikacyjnych „Cyfrowa szkoła”, Instytut Badań Edukacyjnych, Warszawa.

Erasmus + Programme Guide. Valid as of 1 January 2014. Version 3: 09/04/2014 (2014), European Commission, Brussels.

Ordon U., (2007), Kompetencje językowe I komunikacyjne współczesnego nauczyciela Edukacji elementarnej, „Edukacja Elementarna w Teorii i Praktyce: Kwartalnik dla Nauczycieli", 4.

Pachocki M. (2016), Mobilni nauczyciele zmieniają swoje szkoły, Fundacja Rozwoju Systemu Edukacji, Warszawa.

Postholm M.B. (2012), A Completed Research and Development Work Project in School: The Teachers' Learning and Possibilities, Premises and Challenges for Further Development, „Teaching and Teacher Education”, 3(27).

Rozporządzenie Parlamentu Europejskiego i Rady (UE) nr 1288/2013 z dnia 11 grudnia 2013 r. ustanawiające „Erasmus+”: unijny program na rzecz kształcenia, szkolenia, młodzieży i sportu oraz uchylające decyzje nr 1719/2006/WE, 1720/2006/WE i 1298/2008/ WE (2013), Parlament Europejski i Rada Unii Europejskiej, Bruksela.

Smoczyńska A., Chojnacki M., Fells-Górowska M., Grabowska A., Płatos B. (2014), The System of Education in Poland, Fundacja Rozwoju Systemu Edukacji, Warszawa. 


\section{ZAPOTRZEBOWANIE NA WSPARCIE SAMORZĄDÓW SZKOLNYCH}

\section{Abstract \\ The demand to support student governments}

The paper is focused on the problems of student governments. A student government is a place where students learn the mains principles of democracy. The task of a school is to identify natural leaders and help them develop their competences. A school should prepare good leaders who could work at social and public areas. The result of this process depends on how teachers are prepared to work with students. In this paper we aim to identify advantages and disadvantages of student governments. The study was made at secondary schools in the north-western Poland. In total, 464 students and 41 teachers were studied. The results suggest how to support student governments. The study indicates that both students and teachers have limited knowledge about the mains principles and tasks of student governments. The respondents differ in their perception of advantages and disadvantages of student governments.

Keywords: student government, demand for support, prevention

\section{Streszczenie}

Artykuł poświęcony jest problematyce samorządności szkolnej. To obszar działań szkoły, który ma nauczyć zasad demokracji. W ramach tej edukacji zadaniem szkoły jest zidentyfikowanie naturalnych liderów oraz stworzenie im warunków do rozwoju ich kompetencji, aby w przyszłości mogli w sposób odpowiedzialny pełnić funkcje społeczne czy instytucjonalne. Skuteczność tego procesu zależy od przygotowania nauczycieli i doboru treści edukacyjnych do pracy z młodzieżą. Stąd też w pracy podjęto zadanie zidentyfikowania atutów i ograniczeń samorządności szkolnej w środowisku uczniów wybranych szkół ponadpodstawowych województwa zachodniopomorskiego. Pytania o zapotrzebowanie na wsparcie samorządu szkolnego zadano uczniom i nauczycielom. Łącznie przebadano 464 uczniów i 41 nauczycieli. Wyniki pozwoliły na określenie kierunku działań wspierających samorządność szkolną. Wskazują na ograniczoną wiedzę na temat istoty samorządu szkolnego i jego zadań, zarówno w percepcji uczniów, jak i nauczycieli. Badani też inaczej spostrzegają atuty i ograniczenia liderów samorządu.

Slowa kluczowe: samorządność szkolna, badanie zapotrzebowania, wsparcie, psychoprofilaktyka 